\title{
Working
}

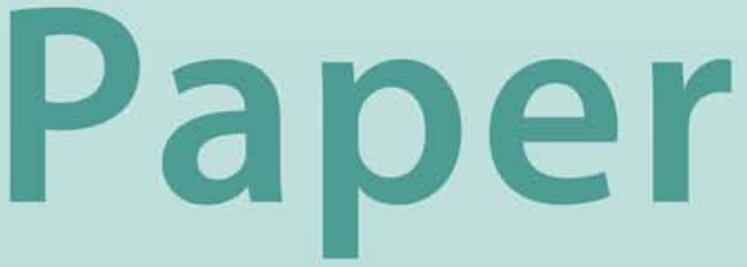




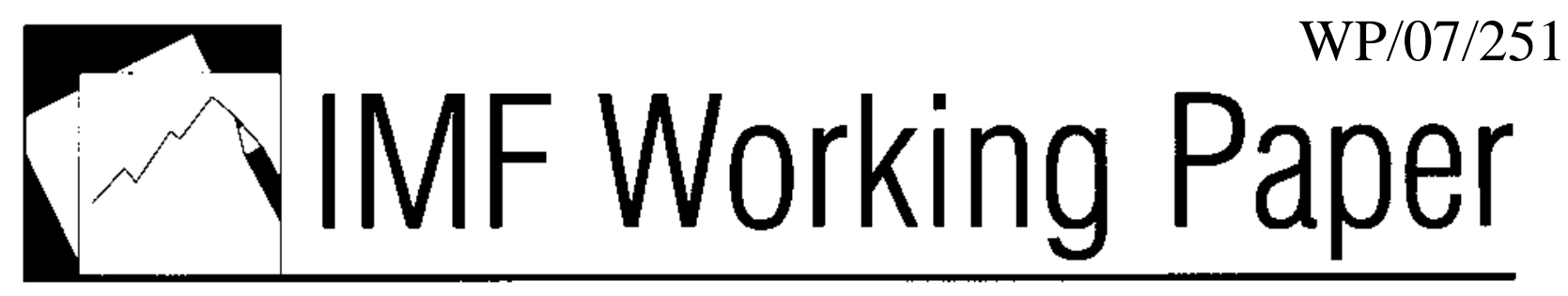

\title{
Capital Account Convertibility and Risk Management in India
}

\author{
Amadou N. R. Sy
}




\title{
IMF Working Paper
}

Monetary and Capital Markets Department

\section{Capital Account Convertibility and Risk Management in India}

Prepared by Amadou N. R. Sy ${ }^{1}$

Authorized for distribution by Udaibir S. Das

October 2007

\begin{abstract}
This Working Paper should not be reported as representing the views of the IMF.

The views expressed in this Working Paper are those of the author(s) and do not necessarily represent those of the IMF or IMF policy. Working Papers describe research in progress by the author(s) and are published to elicit comments and to further debate.

This paper takes a closer look at the prudential and regulatory measures needed to prepare India's financial system to manage the risks arising from fuller capital account convertibility (FCAC). The paper contributes to the debate on FCAC in two ways. First, it reviews the potential and existing financial stability challenges to FCAC in India. Second it studies how prudential regulation and supervision is addressing these challenges. The main conclusion is that regulatory and supervisory measures alone are not enough and will need to be complemented by improvements in Indian banks’ risk management and further development of the domestic capital markets.
\end{abstract}

JEL Classification Numbers: F30, F41, F42, G21

Keywords: India, capital account, convertibility, risk management

Author’s E-Mail Address: asy@imf.org

\footnotetext{
${ }^{1}$ The author wishes to thank Wanda Tseng, Ananthakrishnan Prasad, Abdessatar Ouanès, Charles Kramer, Aditya Narain, and RBI staff for their useful suggestions or comments. A version of this paper is forthcoming in The Analyst, Institute of Chartered Financial Analysts of India.
} 
Contents

Page

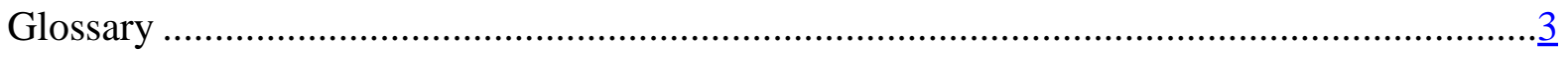

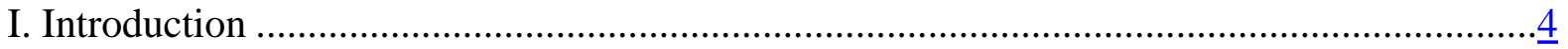

II. What Are the Existing Challenges to FCAC? .............................................................

III. How Is Prudential Regulation and Supervision Addressing the Challenges From FCAC? $\underline{8}$

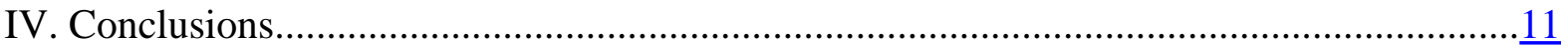

Table

1. Selected Risk Management Initiatives ...................................................................... 


\section{GLOSSARY}

ALCO

ALM

DGA

FCAC

FICCI

HR

IRB

OBS

OTC

RBI

TGA
Asset and Liability Management Committee

Anti-money laundering

Duration Gap Approach

Fuller Capital Account Convertibility

Federation of Indian Chambers of Commerce and Industry

Human Resources

Internal Rating Based

Off-balance Sheet Exposures

Over-the-counter

Reserve Bank of India

Traditional Gap Approach 


\section{INTRODUCTION}

Capital account convertibility refers to a policy change that permits capital to flow more freely in and out of a country. Ishii and Habermeier (2002) provide a thorough analysis of the implications of capital account convertibility for financial stability. In India, recent policy discussions culminating with the publication of the Tarapore Report (2006) have reopened the debate about the risks and benefits of capital account convertibility. ${ }^{2}$ A debate which had lost steam after the Asian crisis. This paper attempts to contribute to this debate and takes a closer look at the prudential and regulatory measures needed to prepare India's financial system to manage the risks arising from fuller capital account convertibility (FCAC).

There are benefits to fuller capital account convertibility for financial institutions, including increased diversification, greater access to capital, and a broader range of risk management tools. However, policymakers, financial institutions, and their clients typically face additional challenges with fuller capital account convertibility. At about US\$104 billion, total foreign bank claims on India are comparable to those on China and Russia. In contrast, Indian banks claims on other countries are four times less than this total. With fuller capital account convertibility, new risks will arise as cross-border transactions increase. Such activities will not only involve different currencies and span many countries but also include on-balance sheet lending and funding, as well as off-balance sheet derivatives and other complex financial transactions.

Increased cross-border transactions will augment the dimensions of risks that Indian financial institutions face in their domestic markets. Market risk-the risk of losses in on- and off-balance sheet positions arising from movements in market prices — changes with cross-border transactions. Similarly, credit and liquidity risks, the risk in derivatives transactions, legal risk, and the risk of regulatory arbitrage include new dimensions: ${ }^{3}$

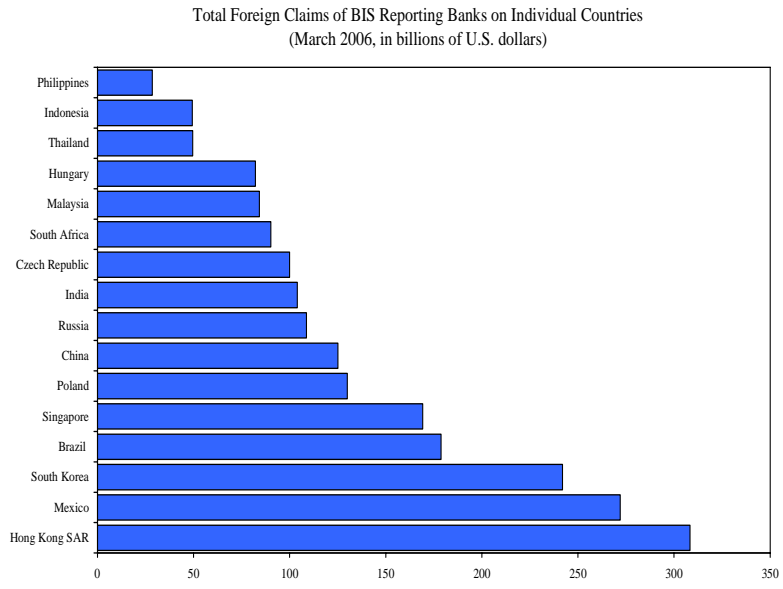

\footnotetext{
${ }^{2}$ The Tarapore Report (2006) notes that "capital account convertibility refers to the freedom to convert local financial assets into foreign financial assets and vice versa. It is associated with changes of ownership in foreign/domestic financial assets and liabilities and embodies the creation and liquidation of claims, on or by, the rest of the world."

${ }^{3}$ See Shogo Ishii and K. Habermeier, 2002, “Capital Account Liberalization and Financial Sector Stability,” IMF Occasional Paper 211, Washington, D.C.
} 
- Market risks such as interest rate and foreign exchange risks become more complex as financial institutions and corporates gain access to new securities and markets, and foreign participation changes the dynamics of domestic markets. For instance, banks will have to quote rates and take unhedged open positions in new and possibly more volatile currencies. Similarly, changes in foreign interest rates will affect banks’ interest sensitive assets and liabilities. Foreign participation can also be a channel through which volatility can spill-over from foreign to domestic markets.

- Credit risk will include new dimensions with cross-border transactions. For instance, transfer risk will arise when the currency of obligation becomes unavailable to borrowers. Settlement risk (or Herstatt risk) is typical in foreign exchange operations because several hours can elapse between payments in different currencies due to time zone differences. Cross-border transactions also introduce domestic market participants to country risk, the risk associated with the economic, social, and political environment of the borrower's country, including sovereign risk.

- With FCAC, liquidity risk will include the risk from positions in foreign currency denominated assets and liabilities. Potentially large and uneven flows of funds, in different currencies, will expose the banks to greater fluctuations in their liquidity position and complicate their asset-liability management as banks can find it difficult to fund an increase in assets or accommodate decreases in liabilities at a reasonable price and in a timely fashion.

- Risk in derivatives transactions become more important with capital account convertibility as such instruments are the main tool for hedging risks. Risks in derivatives transactions include both market and credit risks. For instance, OTC derivatives transactions include counterparty credit risk. In particular, counterparties that have liability positions in OTC derivatives may not be able to meet their obligations, and collateral may not be sufficient to cover that risk. Collecting and analyzing information on all these risks will become more challenging with FCAC because the number of foreign counterparts will increase and their nature change.

- Operational risk may increase with FCAC. ${ }^{4}$ For instance, legal risk stemming from the difference between domestic and foreign legal rights and obligations and their enforcements becomes important with fuller capital account convertibility. For instance, differences in bankruptcy codes can complicate the assessment of recovery values. Similarly, differences in the legal treatment of secured transactions for repos can lead to unanticipated losses.

\footnotetext{
${ }^{4}$ The Basel Committee on Banking Supervision defines operational risk, which includes legal risk, as "the risk of direct or indirect loss resulting from inadequate or failed internal processes, people, and systems or from external events."
} 
- Regulatory issues include the risk of regulatory arbitrage as differences in regulatory and supervisory regimes among countries may create incentives for capital to flow from countries with higher standards to those with lower ones. FCAC can also bring a proliferation of new instruments and market participants, complicating the task of financial supervisors and regulators. The entry of large and complex institutions operating in different countries will increase the need for cooperation and coordination between domestic regulatory and supervisory agencies and also with their foreign counterparts.

The preparedness of financial institutions to adequately manage the risks of FCAC depends largely on how well they manage existing financial risks. Financial institutions' ability to identify, measure, and manage risk will vary depending on the quality of internal risk management and control policies_- "the first line of defense.”

Adequate prudential regulation and supervision, and developed capital markets will also be key in addressing the challenges from FCAC. Prudential regulation and supervision will need to encompass the existing and new risks associated with FCAC. In addition, developed capital markets with adequate liquidity, infrastructure, and market discipline are necessary to provide market participants with the relevant risk management instruments.

\section{What ARE THE Existing Challenges to FCAC?}

Indian banks' risk management needs to be improved further to address the challenges from fuller capital account convertibility. The RBI has noted the need to accelerate the speed at which Indian banks have been moving to strengthen risk management systems. ${ }^{5}$ The Tarapore Report also notes that the skill and competency levels required to manage risks will increase under FCAC and call for a very high level of technical proficiency which at present, it judges to be somewhat limited. Similarly, the recent report of the High Powered Expert Committee on Making Mumbai an International Financial Centre (henceworth, IFC Report, 2007) scrutinizes the regulatory framework that would need to be set in place to enable banks and other market participants to manage their risks.

Public sector banks — which dominate the Indian financial system—view human resources (HR) systems as one of the main area in need of improvement. In a recent survey of banks by the Federation of Indian Chambers of Commerce and Industry (FICCI), almost all (92 percent) public sector respondents voiced that they do not have sufficient autonomy to offer attractive incentive packages to their employee to ensure their commitment levels.

\footnotetext{
${ }^{5}$ See Special Address by Smt. Shyamala Gopinath, Deputy Governor at the FICCI-IBA Conference on "Global Banking: Paradigm Shift,” September 27, 2006, Mumbai.
} 
Interest rate and liquidity risk management remains also limited. The RBI has noted that most banks, although they have put in place an ALM framework, have not internalized it as part of their overall risk assessment and capital planning strategy and face data limitations. As a result, the role of asset and liability management committees (ALCO) remains narrowly confined to decisions on interest rates.

The growth of derivatives in the off-balance sheet items of banks needs an accompanying regulatory and supervisory framework. Off-balance sheet exposures (OBS)—mainly derivatives — of Indian banks have grown rapidly in a highly concentrated market. Market activity in the OTC derivatives market has quadrupled from 1998 to 2004, as indicated by the BIS Triennial Central Bank Survey (2005). This market is highly concentrated as combined share of the top 15 banks has steadily grown from around 74 percent in March 2002 to 82 percent of total OBS exposures of the banking system in March 2006, of which 62 percent is accounted for by foreign banks. An adequate prudential and regulatory framework to address risks in derivatives transactions will need to be developed.

The recent Tarapore report also stresses a number of key requirements for FCAC. In particular:

- To better manage liquidity risk, the report recommends that banks monitor their liquidity position at the head/corporate office level on a global basis, including both at the domestic and foreign branches. In addition the liquidity positions should be monitored for each currency.

- Regarding market risk, the report recommends that banks adopt a duration gap analysis and consider setting appropriate internal limits on their interest rate risk exposures. The Tarapore report also suggests that the RBI link the open position limits to banks' capacity to manage foreign exchange risk as well as their unimpaired Tier I capital.

- Banks will require more derivatives instruments to mitigate the possible risks from fuller capital account convertibility. These should include interest rate futures and options, credit derivatives, commodity derivatives, and equity derivatives, which are not effectively available to banks at the moment. The RBI should, however, put in place the appropriate infrastructure, including a robust accounting framework; a robust independent risk management framework in banks, including an appropriate internal control mechanism; appropriate senior management oversight and understanding of the risks involved; comprehensive guidelines on derivatives, including prudential limits wherever necessary; and appropriate and adequate disclosures. prudential limits wherever necessary; and appropriate and adequate disclosures. 
The IFC Report (2007) notes the need for the following measures to be taken to enable commercial banks offer or use risk management services:

- Operations in derivatives for hedging risks of the core commercial banking book and for clients on an agency basis.

- Identical structure for currency, interest rate, and credit derivatives markets, regardless of whether they are denominated in local or foreign currency.

- Ability to hedge political risk through derivatives and insurance.

- Ability to hedge market risk and operational risk.

\section{How Is Prudential Regulation ANd Supervision Addressing the CHALLENGES FROM FCAC?}

In recent years, the RBI has taken a number of initiatives to gradually strengthen banks' risk management practice to internationally best practice (see Table 1). The Indian authorities have also taken a number of initiatives more recently to address current gaps in risk management regulation and supervision. These cover key areas such as:

\section{Liquidity and Interest rate risks}

To address shortcomings in interest rate risk management, the RBI has advised the use of impact and scenario analysis of changes in yield structures. Regarding liquidity risk management, the RBI has issued in 2006 draft guidelines to banks advising the use of a duration gap approach (DGA) in conjunction with the traditional gap approach (TGA) prevalent in most banks. In terms of the draft guidelines, banks would be required to compute the volatility of earnings and equity under various interest rate scenarios, and fix internal limits under both and earnings and economic value perspective.

\section{Risks in derivatives transactions}

The recent legal recognition of the OTC derivatives market is a key pre-condition for better risk management practice. The amendment of the RBI Act in 2006 helps overcome the limitation of the Securities Contract Regulation Act which gave specific legal recognition to exchange-traded derivatives but not OTC derivatives. The RBI also now regulates the interest rate and foreign exchange OTC derivatives market and has set up an internal group to formulate new comprehensive guidelines in replacement of the existing ones, which focus on specific derivatives instruments. 
Table 1. India. Selected Risk Management Initiatives

\begin{tabular}{|c|c|}
\hline Risk Management & $\begin{array}{l}\text { - Market Risk Management Guidance Note }(2002) ; \\
\text { - Credit Risk Management Guidance Notes }(2001,2002) \text {; } \\
\text { - Risk Management Systems in Banks Notes }(1999) .\end{array}$ \\
\hline Risk-Based Supervision & - Risk Based Supervision Discussion Paper (2001) \\
\hline $\begin{array}{l}\text { Asset-Liability } \\
\text { Management (ALM) }\end{array}$ & $\begin{array}{l}\text { - Guidelines on ALM Draft Amendments (2007) } \\
\text { Improvements to ALM framework, including direction gap } \\
\text { approach (DGA) and granular approach to liquidity risk } \\
\text { measurement (2006); } \\
\text { - ALM Guidelines (1999). }\end{array}$ \\
\hline Operational Risk & - Operational Risk Guidance Note (2005) \\
\hline Stress Testing & - Stress Testing Guidelines (2006) \\
\hline Derivatives Instruments & $\begin{array}{l}\text { - Draft Guidelines on Credit Default Swaps (2007) } \\
\text { - Amendment to the RBI Act (2006) establishing legality of OTC } \\
\text { derivatives, empowering RBI to regulate the interest rate and } \\
\text { foreign exchange OTC derivatives market; } \\
\text { - Derivative/Hedge Accounting Discussion Paper (2006); } \\
\text { - Prudential norms for classification, valuation, and operation of } \\
\text { investment portfolio by banks (2006); } \\
\text { - Fair value accounting in line with IAS } 39 \text {. }\end{array}$ \\
\hline Government Securities & $\begin{array}{l}\text { - Government Securities Bill enacted (2006), allows strips, } \\
\text { hypothecation, pledge, and lien of Government securities, } \\
\text { maintenance of records in electronic form; } \\
\text { - Short-selling in Government securities introduced (2006). }\end{array}$ \\
\hline
\end{tabular}

Sources: RBI

The RBI has taken a number of regulatory measures to address the risks associated with derivatives instruments. These include holding of minimum defined regulatory capital for all OBS exposures, collection of periodic supervisory data and transparency and disclosure requirements. The RBI has also emphasized the need for banks to carry out due diligence regarding customer appropriateness and suitability of products as well as the need to use risk mitigation techniques such as collateral and netting arrangements.

Until recently, the lack of prudential accounting guidelines for derivatives has been a gap in the risk management framework. The RBI has issued in 2006 guidelines for the valuation and accounting of derivatives and more generally banks' investment portfolio (both 2006) to introduce fair value accounting norms for derivatives broadly in line with international accounting norms (IAS 39) with the objective of bringing all derivative transactions "onbalance sheet” as against "off-balance sheet” as being done currently. Finally, commercial banks and primary dealers are now allowed to begin transacting in single-entity credit default swaps. 


\section{Stress testing}

The RBI has recently emphasized the need for banks to have robust stress testing process. The RBI has therefore issued draft guidelines on stress testing (2006), which cover major risk areas. Banks are required to conduct stress tests so as to estimate the resources needed to the resources needed to reduce the risk identified and meet the minimum capital adequacy requirement. Banks have been advised to apply stress tests at varying frequencies dictated by their respective business requirements, relevance, and cost. For instance, exposures to sensitive sectors and high risk category assets would have to be subjected to more frequent stress tests.

\section{Financial sector stability and development self-assessment}

The forthcoming self assessment of financial sector stability and development will be an opportunity for the authorities to assess the preparedness of the Indian financial system to address the challenges for fuller capital account convertibility. This exercise follows the 2001 FSAP and a number of self-assessments of a number of international standards and codes. It will partly rely on the IMF-World Bank Handbook on Financial Sector Assessment (2005).

\section{Basel II implementation}

Basel II aims at making banks' regulatory capital more sensitive to risk and recognizes developments in risk management. In particular it recognizes measurement and risk management techniques employed in the banking sector and accommodates them within the framework such as the Internal Rating Based (IRB) Approach. It also aligns regulatory capital closer to economic capital. As a result, Indian banks with stronger risk management practices would benefit from lower regulatory capital requirements. In contrast, banks with poor risk management-which for instance rely extensively on external ratings—-would be penalized by higher capital requirements.

In particular, Basel II introduces a greater risk sensitivity in the treatment of credit risk, including that associated with cross-border exposures. For instance, risk weights are currently set by asset class (e.g., government, corporates, banks), and range from 0 percent to 100 percent. In contrast, risk weights will depend on the individual risk rating of each counterparty under the Basel II standardized approach and the ceiling risk weight increase to 150 percent. As a result, the capital requirements for credit exposures, including cross-border portfolios, will depend on the risk weights of individual counterparties, and could potentially increase depending on the quality of the portfolio.

The roadmap to Basel II should provide Indian banks a strong incentive to strengthen their risk management practice. Foreign banks operating in India and Indian banks having presence outside India are to migrate to the standardized approach for credit risk and the 
basic indicator approach for operational risk, with effect from March 31, 2008. All other scheduled commercial banks are encouraged to migrate to these approaches no later than March 31, 2009.

\section{ConCLUSIONS}

As recognized in the recent Tarapore Committee Report, financial institutions' ability to identify, measure, and manage risk will also depend on the availability of instruments to manage risk, the liquidity of financial markets and the quality of market infrastructure, and level of market discipline.

Key segments of the Indian capital markets remain, however, underdeveloped. The term money market is limited and although there is a domestic yield curve for government securities with maturities up to 30 years, its depth and liquidity are limited. The corporate bond market is relatively small and illiquid, and the market for securitized assets has fallen short of expectations. The OTC derivatives market is growing rapidly but its prudential and regulatory framework has just been laid out.

The Indian authorities are addressing a number of these issues. For instance, the RBI set up a Working Group on Screen Based Trading in Government Securities in 2004, and Internal Technical Groups on Money Market as well as on Central Government Securities Market in 2005. The recently passed Government Securities Act allows stripping of bonds into separately-tradable principal and interest payments. The recent report by the High Level Expert Committee on Corporate Bonds and Securitization (appointed by the Minister of Finance in 2006) makes a number of recommendations that should be useful for better risk management.

Going forward, it would be useful to revisit the question of what needs to be done to prepare India's financial system to manage the risks from FCAC, by taking a closer look at the measures — and the pace of their implementation — that are needed to develop domestic capital markets accordingly. 


\section{References}

Bank for International Settlements, 2005, “Triennial Central Bank Survey,” Foreign Exchange and Derivatives Market Activity in 2004, Basel (March).

Basel Committee on Banking Supervision, 2001, “Operational Risk,” Consultative Document, BIS.

Gopinath, Shyamala, “Changing Paradigms in Risk Management,” Special Address by Smt. Shyamala Gopinath, Deputy Governor at the FICCI-IBA Conference on "Global Banking: Paradigm Shift,” Mumbai, (September 27).

Ishii, Shogo, and K. Habermeier, 2002, “Capital Account Liberalization and Financial Sector Stability,” IMF Occasional Paper 211, (Washington: International Monetary Fund).

International Monetary Fund, and The World Bank, 2005, IMF-World Bank Handbook on Financial Sector Assessment, (Washington, D.C).

Mohan, Rakesh, 2007, “Risk Management in an Open Market Economy,” Speech by Dr. Rakesh Mohan, Deputy Governor of the Reserve Bank of India at the inaugural programme of the Centre of Advanced Financial Learning, Mumbai, (June 4).

Report of the Committee on Fuller Capital Account Convertibility, 2006. Shri S. S. Tarapore, Chairman.

Report of the High Powered Expert Committee on Making Mumbai an International Financial Center, 2007, Ministry of Finance, Government of India, Sage Publications, New Delhi.

Reserve Bank of India, 2005, “Report of the Internal Technical Group on Forex Markets”.

—_, 2006, “Annual Report 2005-06”. 